\title{
БАЛКАНИЗМЫ В ЧУШМЕЛИЙСКОМ ГОВОРЕ (БЕССАРАБИЯ)
}

\author{
В. А. Колесник
}

Колесник В. О. Балканізми в чушмелійській говірці (Бесарабія). У статті досліджується граматичні та лексичні балканізми (запозичення з грецької та турецької мови) в говірці с. Криничне (стара назва Чушмелія, Чушмелій), яка належить до так званих сиртських болгарських говірок (за назвою місцевості Сърта в Болгарії) і екзотичною на тлі інших болгарських переселенських говірок Півдня України. Досліджується доля граматичних балканізмів в болгарській переселенській говірці (означений артикль, да-конструкції, посесивний датив, редуплікація, граматичний статус лексеми один та ін.), які характерні для болгарської мови як представника Балканського мовного союзу. Значна частина запозичень з грецької та турецької в болгарській мові інтегрована у болгарську діалектну систему. Унікальними $є$ назви одягу, які не зафіксовані в інших болгарських діалектах Бессарабії. Турецький аналог болгарських слів найчастіше переходить до пасивної лексики.

Ключові слова: болгарська діалектологія; болгарські переселенські говірки; граматичні та лексичні балканізми; Балканський мовний союз; запозичення з турецької; лінгвістичні контакти.

Колесник В. А. Балканизми в чушмелийския говор (Бесарабия). В настоящата статия се разглеждат граматичните и лексикалните балканизми (основно заемки от гръцки и турски) в чушмелийския говор (с. Криничное, Болградски район, Одеска област, Украйна), който се отнася към съртските говори в България (по названието на местността Сърта). Това е изключително архаичен говор, чиито езикови особености значително го отличават от другите български говори в Украйна. Изследват се граматичните балканизми (членната морфема, $\partial a$-конструкции, посесивен датив, редупликация и др.), които са характерни и за съвременния български език като представител на Балканския езиков съюз. Значителна част от лексикалните балканизми се интегрира в българската диалектна система. Уникални за говора са названията на облеклото. На съвременния етап от развитието на чушмелийския говор заемките от турски преминават в пасивния лексикален фонд.

Ключови думи: българска диалектология; български преселнически говори; граматични и лексикални балканизми; Балкански езиков съюз; заемки от турски; лингвистични контакти.

Kolesnik V. A. Balkanisms in the Chushmeliy Dialect (Bessarabia) The article deals with the grammatical and lexecal balkanisms (old adoptions from the Greek and Turkish language) in the dialect of the village Krinichnoe (previous name of the village is Chushmeliy), which belongs to the so-called "syrtsky" dialect (the name of its dialect comes from the name of the Bulgarian region Syrta). The article deals with one of peculiarities of grammatical system of Bulgarian transmigratory dialects of the Ukraine - grammatical balkanism (definite article, grammatical status of lecseme one, reduplication) in comparison with Bulgarian language, wich belongs to Balkan language union. The names of the clothes are unique and not registered in any other Bulgarian dialects in Bessarabia. A significant part of the Turkish loanwords in Bulgarian are integrated in the Bulgarian dialect system. The Turkish component variant is usually driven to the passive word stock.

Keywords: Bulgarian dialectology; Bulgarian transmigratory dialects; grammatical and lexecal balkanisms; Balkan language union; Turkish loanwords; linguistic contacts.

Болгарский язык, как известно, принадлежит, с одной стороны, к славянской семье - южнославянской, а с другой стороны - к балканскому языковому союзу (вместе с новогреческим, албанским и румынским $)^{1}$. Длительное функционирование этого языка в балканском языковом окружении изменило, «балканизировало» его грамматический, фонетический и лексический строй, в результате чего он является членом языковой семьи - по отношению к славянским языкам, и одновременно с этим - членом языкового союза - балканского.

Среди других балканских языков место болгарского языка также является особенным. Занимая центральное географическое положение, болгарский язык находился в прямом контакте с каждым из балканских языков и был посредником их взаимовлияния. Полнота и последовательность, с которой представлены балканизмы в болгарском языке, позволила охарактеризовать его как «эталон балканского языкового союза», «инвариант бал- 
канского языкового типа»². Таким образом, он является эталоном балканского языкового союза среди балканских языков и «классическим и экзотическим» ${ }^{3}$ среди славянских.

Причины создавшейся языковой ситуации на Балканах, которая способствовала трансформации синтетических славянских форм в аналитические, в современном балканском языкознании объясняются в основном языковыми контактами. Возникновение балканского языкового союза обусловлено языковой интерференцией, «различными формами билингвизма, восходящими к субстрату, адстрату и суперстрату» ${ }^{4}$. Языковой союз рассматривается как «остановившееся на полпути движение языков к интеграции» ${ }^{5}$. Истоки этого объединения уходят в глубину веков. Весьма вероятно, что уже в ранний античный период под влиянием греческого и латыни сложился языковой союз, в состав которого входили фракийский, дакский, фригийский, македонский и иллирийский языки, причем первые три образовали ядро этого союза. На этот полуэллинизованный, полулатинизованный этнический пласт позднее добавились славянские, протоболгарские, а затем и турецкие наслоения. С этого момента начинается активное взаимопроникновение балканских языков, которое особенно усилилось во времена Оттоманской империи. Двумя-тремя языками владели почти все.

Именно в результате языковых контактов и возникли в болгарском языке инновации, названные позже балканизмами. Под балканизмом понимают «все возможные реорганизации грамматической структуры, вызванные качественными и количественными изменениями в условиях балканской языковой среды», при этом берутся во внимание не только чисто балканские языковые модели, но и различные реорганизации исконно славянского материала в условиях балканской языковой среды ${ }^{7}$.

Основной балканистический инвентарь в области фонетики, лексики и морфосинтаксиса уже известен. В. Георгиев отмечает следующие черты БЯС: на фонетическом уровне - сходство артикуляционной базы в языках БЯС, наличие типичного вокала (ъ) - в болгарском, румынском и албанском. К грамматическим балканизмам традиционно относят: наличие постпозитивного артикля (характерного для румынского, албанского, болгарского, македонского языков); аналитические способы образования форм компаратива и суперлятива (в болгарском, македонском, румынском, албанском и новогреческом языках); удвоенное дополнение (в болгарском, македонском, албанском, новогреческом языках и сербских диалектах); употребление краткой формы личного местоимения в роли притяжательного - посессивный датив (в болгарском, македонском, румынском, албанском и новогреческом языках); угасание инфинитива, его замена да-конструкциями и некоторые другие. В последнее время к грамматическим балканизмам относят также адмиратив и пересказ, учитывая при этом и роль тюркского (турецкого) влияния

Переселенческие балканские говоры, в том числе и болгарские говоры юга Украины - неотъемлемая часть болгарского языкового континуума, несомненно, должны привлекаться при анализе различного типа балканизмов, наибольшее количество которых, по данным нашего исследования, обнаруживают переселенческие говоры так называемого балканского типа. Это выходцы из подбалканских сел, в основном Ямбольского и Сливенского округов. Исконный пласт этих говоров характеризуется наибольшей стабильностью примарных балканизмов - балканизмов первого ранга9.

Говор жителей села Криничное (Чешма-Варуита, Чушмелий) является наиболее экзотичным не только в Бессарабии, но и в Болгарии. Село основано болгарскими переселенцами из так называемых «сыртских» сел, поэтому и говор называют «сыртский». Речь идет о говорах 11 сел, расположенных в районе «Сърта» (Шуменского округа): Кюлевча, Каспичан, Марково, Косово, Снежина, Градинарово, Неново, Равна, Кривня, Черковна, Овчарово. Села находятся на территории между Шуменом, Преславом, Новым Пазаром и Провадией, т.е. там, где процветала культура Первого болгарского государства.

Впервые на специфические особенности сыртского говора обратил внимание известный болгарский диалектолог Любомир Милетич (1902 г.), затем - Беньо Цонев. Некоторые особенности сыртского говора были предметом научного спора между профессорами Л. Милетичем и Б. Цоневым. Б. Цонев утверждал, что носители этого говора переселились с юга, о чем свидетельствуют некоторые особенности южных болгарских говоров в чушмелийском диалекте. Любомир Милетич считал сыртские говоры наиболее архаичными (старинными) среди исконных мизийских. 
Л. Милетич определил и период миграции носителей говора с. Каспичан на север 1812 г. Болгарское население здесь значительно сократилось именно после 1812 г., когда после русско-турецкой войны отсюда ушло много болгарских семейств. Те, которые перешли через Дунай в Валахию, некоторое время жили около г. Калараш, а оттуда ушли в Бессарабию и осели в с. Чешмели, другие обратно перешли Дунай и расселились в Силистренском округе, главным образом в с. Алмалой (сейчас на территории Румынии). Из Шуменского округа почти целиком ушло население четырех сел: Могилы (к югу от г. Нови Пазар), Равны, Кривны (к северу от Провадии) и Новосела. Кроме того, как уже отмечалось, часть населения ушла из с. Каспичан. В Бессарабии болгары поселились в четырех различных селах: Чешма-Варуита, Бабели, Анадол и Кубей. В 1860 г. часть населения сел, которые отошли к Молдавскому княжеству и потеряли все льготы, переселилась на русскую территорию - в Таврическую губернию, в район Северного Приазовья. Выходцы из Чешма-Варуиты в Приазовье основали с. Богдановку, а небольшая часть чушмелийцев вместе с выходцами из Болграда поселилась в соседнем с. Степановка.

Жители бессарабской Чешма-Варуиты очень консервативны в своем быту. Примечательно, что и в Приазовье чушмелийцы сохраняют до сих пор такие этнографические особенности, которые в других селах давно уже утрачены.

Чрезвычайную архаичность быта жителей села отмечал еще Н. С. Державин: «Это село дало мне наиболее полный этнографический материал, настолько полный, что в других селах той же Бессарабской губернии я находил только осколки того быта, который мною был записан в этом именно селе. Причины такой этнографической устойчивости в данном случае я склонен видеть исключительно в языке. Чушмелийский говор, шуменский по происхождению, настолько резко отличается своими фонетическими, морфологическими и лексическими особенностями от всех окрестных болгарских говоров, что чушмелийцы у своих соседей постоянно служат мишенью насмешек. Такого рода положение вещей сказалось на этнографической и национальной обособленности чушмелийцев: осмеянные соседями, они как будто невольно отгородились от них и продолжали жить своим собственным национальным запасом ${ }^{10}$.

Только в чушмелийском говоре шелковичный червь называется тишть, маленькое полотенце - рума , сани - къзъки, къзачки (болг. лит. шейна), пчела - бръ.ббл, баница - зельник, идет дождь - лити дъш (болг. лит. вали дъжд), ткацкий стан называется криватини, шелковая нить - бирин'дж'ук, техника изготовлений полотенец - късан'e, полотенца, изготовленные по этой технологии - късани пишкир'е.

Материалы нашего исследования свидетельствуют и о том, что в чушмелийском говоре сохранилось много архаичных славянских по происхождению лексем, вместо которых в других болгарских бессарабских говорах употребляются заимствования из турецкого, румынского или греческого. Это частоупотребительные лексемы: прозурц - ‘окно' (в большинстве болгарских бессарабских говорах - джам, n'ен'дж' $y p$ ), гражд - 'загон для скота (овец) во дворе' (в других бессарабских болгарских говорах - хагъл, агъл, кошара, сайван, сая, дам, пирде), котел - медное ведро (в других бессарабских болгарских говоpax - бакър), убил 'колодец' (в других бессарабских болгарских говорах - гиран, бунар, кладени, клаяни), опас - 'пояс, колан' и др.

В то же время этнографы и лингвисты отмечают, что жители с. Криничное отличаются своеобразным диалектом, особой архаичностью быта и сильным тюркским субстратом ${ }^{11}$. $\mathrm{B}$ терминологии родства, например, это проявляется в наличии ряда тюркских терминов, вместо которых у болгар Украины и Молдовы употребляются славянские по происхождению термины: каинчу вместо шуряк (брат жены) - от тур. kayinçe 'по-млад шурей, девер'12.

Многие из этих лексем зафиксированы не только в турецком, но и в других балканских языках, поэтому их принято называть лексическими балканизмами. К таковым относят одинаковые лексические элементы по большей части турецкого или греческого происхождения, которые функционируют во всех балканских языках первого ранга (албанский, румынский, болгарский, македонский). Есть среди них и топонимы, гидронимы и антропонимы. Наиболее полный перечень лексических балканизмов представлен в словаре В. Будзишевской.

Заимствований из турецкого языка в чушмелийском говоре действительно больше, чем в других бессарабских болгарских говорах, и сохранились они в той фонетической 
форме, которая ближе к турецкой (шакъ 'шутка', срв. болг. шега), и их значение, как правило, совпадает со значением этой лексемы в турецком языке или в турецких говорах (срв. дувар' от тур. duvar 'стена').

Среди частоупотребительных слов в чушмелийском говоре, как и во всех болгарских бессарабских говорах, фиксируем много заимствований из турецкого, которые употребляются и в других балканских языках. Это лексемы: айдутин, алтън, акъл, алкъ, аман, арман, арпаджик, атил, айат, бадж'анак, баир', байр'ак, бакър, барим, барут, басамак, батак, баур (бахур), башкъ, башчъ, б'ел', б'ел'ни, б'ел 'ким, бириндж'ук, булгур, бустан', бутуш, буйа, гага, гайдарджийа, г'ега, г'евр'ек, г'ол' (езеро), дангъ (петно), джоб, джум'ер 'ки, дж'уна, д'ер'ек, дзимбил' (зюмбюл), дикан', дувар', душманин, ийнийа (яхния), ил'а са, имиш, имурук (юмрук), каба, кавърмъ, казан (кофа), каиш, каймъ (кисело зеле), калгъ (кавга), калпак, калтърмъ (юзда), кальп, камчийа (камшик), камъ (кама), късм'ет', катал 'асам, катран', каър (кахър), кир'еч, копч'е, кудж'а, кудук, кумшийа, кундил', курбан, курдисан, кур'ем, кър, лаут', магари, мазийа (мазе), маймуна, макар, мандж'а, маскаръ, м'егдан', м'еджийа, мукайет', мустак, мусура (муиуна), мууль (махала), надж'ак, падар', пазар', патладж'ан, пафти, писк'ул', пишкир', пишм'ан, ракийа, сайван, сакат, сапун', сармъ; сини, сувръ, сууръ (софра), сулдърмъ, сурат, с'урийа, таван, таласъм, таман, тармък, тарпан, mon, m'ym 'ун', ч'аршау, ч'атал, ч'аун', ч'енийа, чивътин (чефутин), чииз, чизми, чикил'ек, чикм'аджи, чикрък, чушми (чешма), чубан, иувал' (чувал), ч'укан', ч'умбър'а, ч'умб'ер', ч'урап, ч'урбъ, шакъ (шега), шамар'; шарапанъ, ширпанъ (шарпана); шил'е, шиши (шише), йав 'ар' (хайвер), йанд'ек, йаральк и др.

Немало в чушмелийском говоре и заимствований из греческого языка. Это лексемы: вравель - гривна 'браслет' (в Восточной Болгарии врахель, врахал), криватини - тькачен стан 'ткацкий станок', ско́минь - пейка 'скамейка', стра́кина - паница 'глубокая тарелка', каниска - 'дар, който се носи на сватба или на кръсник' и др.

Младшее поколение уже не помнит значения слов: арнисам 'завършвам', асъ 'хасе, памучен плат', acmap' (хастар 'подплата на дреха'), г'ердел' 'бъчва за сирене', г'етл 'ук 'част на каруцата', гив'ач 'супник', дарак 'уред за влачене на вълна', димийа 'домашно изтъкан вълнен плат', дингил' 'дървена ос на волска кола', дисаги, д’yc 'много, силно', йентерийа 'яке от домашен плат' и многие другие.

Все реже употребляются лексемы:

абе́р' м. 'вест, известие' болг. хабер 1. 'вест, известие'; 2. 'познание, понятие' (ар.тур.) ${ }^{13}$ [Кату виждаш пайак, ш'е имаш аб 'ер'; Мама испруоди на m'ат'у аб 'ер' да си дуод’а по скору];

adém' м. 'обичай' болг. разг. aдеm 1. 'обичай, ред, установен като норма в дадена среда или колектив’; 2. 'навик, нрав на човек или животно’ (ap.-тур.) ${ }^{14}$, чрез тур. adet от арабски ${ }^{15}$ [Имаши такози ад'ет'];

адъ.м м. 'крачка' - от тур. adem също [Тий са м'аст'ат на идин адъм];

алтаньджи́к м. 'латинка', болг. алтънка произв. от тур. altin 'жълтица, златен'16 [Алтан'джику цафт'е вътр'а градин'ката];

бой м. 'ръст' - от тур. воу ${ }^{17}$ [Ни ми са нрав'ат ора аз мънич'ук бой; Той има гул'ам бой];

гив 'ез 'ан прил. 'виолетов, лилав' - болг. диал. гевезен 'тъмновишнев' (Българи, Мичуринско) - от тур. guvez 'виолетов, лилав' ${ }^{18}$ [Кандилката гив'ез'ана ияафти кат кандилу];

z'eд 'yк м. вдлъбнатина 'впадина' - вероятно от тур. gedik 'цепнатина, пукнатина'19 [Г'ед'ук-дупка на път' 'y];

г'ен 'г'ер' м. магарешки бодил 'татарник колючий' - от тур. диал. ginger камилски трън ${ }^{20}$; г'ерд'ел м. дървена бъчва за сирене 'деревянная бочка для брынзы' - неясного проис-

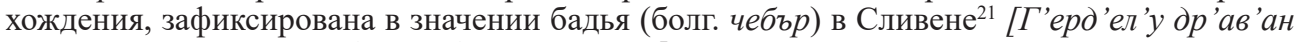
за сир'ен'е, кис'ело грозд'е, на д'есит казана];

далгъ ж. вълна 'укр. хвиля' [B'атро нагони многу далг'a. (Софийско; Кюстендилско; СИ; ЮЗ)] - от тур. dalga също 22 ;

дангъ ж. дамга, петно 'пятно' [Тъз дангъ ни съ испира] - от тур. damga също ${ }^{23}$;

зара́р ж. 'вреда, лошо' остар. разг. 'загуба, вреда, щета' - чрез тур. zarar от араб. ${ }^{24}$ [Да напраши на тойа ч'ул'ак зарар]; 
кулай ч. результат, возможность - от тур. kolay 'лек, лесен; способ, начин'25 [Bacnumвам, васпитвам, н'ама никакуу кулай. Да има кулай, ша си ида хот' зор'а].

nафти мн. 'пафта, украсена метална плочка за закачване на женски колан' [Носи пафти - син'кит'а знайат чи т'а й згуд 'ена];

урсузлук м. 'злъст, злоба' болг. разг. урсузлук '1. проклетия, злоба, подлост; 2. постьпка от проклетия, злоба, подлост’ (тур. ${ }^{26}$ [Имаш многу урсузлук];

чунн 'ким предл. 'поради, по причина на' [Ч'ун'ким си купи н'ашта и са вали. Ч'ун 'ким завана дъши ни утидууми да купами];

кимбе́m' ж. 'пещ' болг. диал. 'лежанка на печка' - от тур. kümbet ${ }^{27}$, кюмбе 'тухлена печка' зафиксировпна в с. Кръвеник, Севлиевско [Ний спим на кимб’ет' 'y];

кирили́у прил. 'мръсен' болг. разг., произв. от тур. kır 'нечистотия; мърсотия; нечистотия по тяло или долни дрехи от пот и прах ${ }^{28}$ [Н'аштата ти кирливи].

Заимствования из турецкого языка - яркие свидетельства пятивекового турецкого владычества - в чушмелийском говоре действительно сохранились дольше, чем в других болгарских бессарабских селах. Это, например, названия одежды:

вистань - рокля от по-тънък плат, фустан 'женское платье из тонкого полотна'; малагамба - 'горна риза от вълнена тъкан';

$\boldsymbol{y m a}$ - престилка от груб плат или кожа 'передник из грубой ткани или кожи'; $\boldsymbol{c u \boldsymbol { \mu }}$ джсо - материя, с която е подшита роклята // подгъв на рокля 'материя, которой было подшито платье' // 'запас, подгиб'- от тур. диал. sincaf 'край на пола' [Вистан'y путшит сас синдж'оф $]^{29}$;

тистиме́ль кърпа, забрадка 'платок' [Тистим'елу са носи зимну вр 'ам'е пут ш'ал'ч'е. Мама ми изнеси идин тистим'ел'; Ти з'е ли си тистим'ел' $a$ ?] заемка от перс.-тур. също ${ }^{30}$; тистиме́л'чи, тистимел'ча - носна кърпа 'носовой платочек';

каплама - 'верхняя женская одежда': Горн'у убл'акло за жин'а - каплами. Эта лексема встречается в Болгарии в Силистренском, Котленском, Казанлыкском округах, а также и в других балканских языках - новогреческом, арумынском, сербском, хорватском, румынском, и поэтому ее относят к лексическим балканизмам ${ }^{31}$.

Лексема вес в чушмелийском говоре имеет значение 'женска шапчица': $B$ 'ес нос'ъm зимъта пут касинката да ни замръзни главътъ.

К другим редким заимствованиям из турецкого следует отнести лексему лала́нги 'оладьи': Т'асту аз дрожд 'а ж 'ар 'ам на ч'аун'ч'а аз улой и са пулуч'ават лаланги, пуд 'ер 'то ги пусипват ас сахарна пудра. Баба ж'ари лаланги ут т'асту аз дрожд'а на ч'аун'ч'а аз улой. Эта лексема известна и турецким говорам, куда пришла из новогреческого, а в Болгарии зафиксирована в Севлиевском округе в другом значении - 'вид каши с яйцом и мукой' - от тур. lalanga 'вид тестен сладкиш (возм. от нгр.)'32.

Чаще в болгарских бессарабских говорах встречается название лепешек с брынзой или сыром гизл'ами 'вид тестено изделие', болг. диал. гъозлеме, гюзлюма 'вид тестено ядене' (Нова Надежда, Хасковско) - от тур. gözleme [Напр'ат' прайава гизл'ам'а, тий жар'ава са].

К раритетным следует отнести также название вида каши из муки ешмерийа 'вид каша от брашно, масло и вода' [Жари са мас саз брашну, налива са уда, с'етн'а са вари кат кашичка] - возможно от тур. еsmer 'възчервен, мургав', ешмерия каша зафиксирована в с.Момино, Варненско ${ }^{33}$.

Лексема мангър также заимствована из турецкого языка, где имела значение 'старинная мелкая медная монетка', в Болгарии зафиксирована в Плевенском округе в значении 'нищо': мангър не разбира - нищо не разбира 'ничего не понимает'. В этом же значении лексема употребляется и в чушмелийском говоре: 'нищо (без значение)' Kp'ecu си лии'ету дурд 'е и алтън, кат станиш мангър и на б'ал Дунау да мииш', н'ама да и умииш'. Примечательно, что лексема мангър заимствована из турецкого во все балканские языки (сербский, хорватский, греческий, румынский $)^{34}$.

Турецкой по происхождению является и лексема пандж’'áp' - цвекло 'свекла', которая фиксируется в Болгарии не только в Шуменском и Варненском округе, но и в Софийском и Гоцеделчевском.

Лексема сини 'софра' проникли в турецкий из персидского или арабского - букв. 'от Китай, китайски', в чушмелийском говоре употребляется в значении 'круглый низкий 
стол для еды', хотя в настоящее время ее уже как стол не используют. В Болгарии лексема зафиксирована в Шуменском округе и в Разградском, а в Бессарабии употребляется также в с. Суворово (Шикирли-Китай), Кулевча и некоторых других. Лексема зафиксирована и в срхр., рум., алб., арум., нгр. ${ }^{35}$.

\section{К лексическим балканизмам относятся также лексемы:}

ка́вель ж. 'подарьк на сватба' [Читвъртук сватуут'е дунас'ат кав'ел']: кавел, кавул диал. 'сьгласие, споразумение' (Преславско). - чрез тур. kavl, kavil 'дума, разговор; споразумение, уговаряне’ от араб., заето и в срхр., алб, нгр. - сродно с каил

кадър, кадърен прил. 'способен' болг. остар. 'годен, способен'- чрез тур. kadır 'могъщ, всесилен; способен' от араб. също; заето и в срхр., алб, арум ${ }^{37}$ [То мумич'а кадърно, хубуу, умну, зна сичкуту да направи. То такос кадърно можи синкуту да прай. Такозик кадра];

мамуди́я ж. 'златна монета' болг. остар. махмудия 'стара турска жълтица от 25 гроша' - чрез тур. mahmudiye от араб., заето и в срхр., рум., арум., дакорум., алб., гр. ${ }^{38}$ [Мамудийа по-гул'ама ут алтьн];

мундарль'к м. 'пъпка' болг. мурдарльк, мундарльк 'гнойни пьпки у бебета' (Казанлък, Самоковско, Шумен); 'кожно заболяване у новородено дете, вид пъпки, които излизат по лицето и главата у малки деца, гнойни мехурчета по кожата' - от тур. murdarlik също. Заето и в срхр., арум. ${ }^{39}$ [Дит 'ету има мундарльк];

мускъ ж. 'вид шарка; амулет' [Вистан'у на муски], болг. муска 'талисман' - от тур. 'амулет, талисман' ${ }^{40}$. Лексема муска в диалектах может иметь значение: 'украшение на мохамеданка' (Родопите), 'вид украса на дреха' (Котленско), 'вид шарки на женски колан' (Бериево, Севлиевско), 'връхна женска дреха' (Марковча, Шуменско), 'амулет (Средни Родопи), който може да се сложи под дрехите на новороденото и родилката - против магия, уроки, главоболие и друго'.

Турцизмы и грецизмы, как правило, имеют в говоре субституты - заимствования из русского языка: вместо чеиз - придану, алтън - золото, кумшия - сосед, стомах - желудок, зюмбюл - гиацинт, буя - краска, боядисам - красявам, крася, лале - тюльпан, люляк - сирень, пирон - гвоздь, джумерки - шкварки, имиш - сладусти, топче - мяч, хагъл сарай, таван - паталок. В речи среднего поколения все чаще употребляются русизмы: адд'ел'ну (башка), краска (буйа), буханка (самун), знак (нишан). Семантическое размежевание дублетних компонентов, семантическая дифференциация приводит к образованию смысловых, идеографических синонимов.

Огромное количество заимствований из турецкого и греческого языков в чушмелийском говоре свидетельствует не только об активных прямых языковых контактах в прошлом, но и об удивительной консервативности, стабильности и неизменности основного диалектного фонда. Это один из основных признаков болгарского этнического и субэтнического самосознания чушмелийцев. Многие из раритетных заимствований имеют ограниченное территориальное распространение, они разпространены в основном в Шуменском, Новозагорском, Разградском округах, но и в Казанлыкском, Чирпанском, некоторые в Хасковском, в Страндже и могут быть маркерами чушмелийского говора, в котором удивительным образом переплетаются черты северных и южных болгарских говоров.

К балканским особенностям на фонетическом уровне следует отнести наличие гласного $\mathbf{b}$, который в говоре имеет более задний характер, отличается от обычного более высоким подъемом языка и произносится под ударением независимо от происхождения гласной (удъ, усиъ, главъ, пиръ, бакър). Слова женского рода на а с ударением на флексии, как правило, имеют окончание ь: $y \partial ъ$, брадъ, главъ, горъ, горъта, усиъта; в произносится и во флексии глаголов 1 л. ед.ч. настоящего времени - nupъ, npuдъ, мuтъ.

На морфологическом уровне это прежде всего наличие постпозитивного артикля (в чушмелийском говоре сущ. и прилаг. м.р. ед.ч. имеют артикль -о): Кукошката с'ади на гн'аздоту. Мажо кр'ашти пу пазар'у. Са збират жин'ат'а ут муулъта, мъжит'е прайат кум'едийа.

Аналитические способы образования форм компаратива: Д'ал'ничнит 'е варти ут попрос мат 'ерийал, пак за празник - ут по-скъn.

Удвоенное дополнение: Накутр'а д’аца ги изнас 'ат на път' 'у. Бабичката йа пълн'ат. Абълката йа тур'ат на байр'аку. 
Употребление краткой формы личного местоимения в роли притяжательного посесивный датив: Л'ел'а ми жув'а със сим'ействуту си на Измаил.

Наличие да-конструкций вместо инфинитива: Искам да йам. Заваштат да грибът.

Обилие беспредложных конструкций: $A c$ ca учи дис'ет' 'yy клас 'Я учусь в десятом классе'; Ас ж'ув 'ам с'елу 'Я живу в селе'; Баба ми б'аши зв 'енавойка калхозу 'Моя бабушка была звеньевой в колхозе'; Л'ел'а ж'ув'а Исмаил 'Моя тетя живет в Измаиле'. Беспредложные конструкции в 70-80 гг. под влиянием русского языка начинают заменяться предложными: Родила съм се в с'ент'абр'е 'Я родилась в сентябре'.

Специфической особенностью грамматической системы чушмелийского говора являются колебания в роде, несогласование существительных по роду в атрибутивных сочетаниях. Так, к женскому роду относятся некоторые заимствования из турецкого, которые в других болгарских говорах относятся к мужскому - йорк'an'a 'ласка' (болг. лит. невестулка, в других бессарабских говорах - йорпик') и камчийа 'кнут', болг. лит. и в других бессарабских говорах камчик: Тъс мръсната йорк'ап'а ни из'ади син 'кит 'а пул 'уута; Ас камчийата гон'ат кон'y. Лексема чекмедже в чушмелийском говоре также относится к женскому роду, а не к среднему, как в других болгарских говорах, и имеет окончание -u - чикм'еджи: Вътр'а инъта чикм'еджи имаши лъйи'а, вътр'а другата стув'аши л'абу. Вариативные формы (ж. и м. р., ж. и ср.) имеют существительные пан'ер', прол'ат, пръс, уб 'ат, подат', малад 'ош, шиши, к'аши.

Таким образом, чушмелийский говор, как и все болгарские говоры юга Украины часть национальной сущности одного из народов, населяющих Бессарабский край, с одной стороны, и часть балканского народа - с другой. Функционируя почти два столетия в инославянской безартиклевой языковой среде, он сохранил аналитизм грамматической структуры, основные, так называемые примарные балканизмы в именной системе - apтикль, энклитические формы местоимений, удвоенное дополнение, аналитический способ образования форм компаратива, $\partial a$-конструкции. При этом архаичный исконный пласт говора более «балканизирован», нежели современный болгарский литературный язык. Это проявляется прежде всего в чрезмерном гипертрофическом употреблении артикля, особенно в атрибутивных сочетаниях, в обилии гипертрофических (плеонастических) форм с указательной функцией и беспредложных конструкций.

На основании данных второго тома Болгарского диалектного атласа установлено, что сыртский говор в своей основе является северо-восточным, мизийским, но с элементами южных болгарских говоров. Различия, существующие между ним и другими шуменскими говорами, являются следами старого единства всех восточных говоров. Все участники спора, однако, неоспоримым признают факт существования в говоре архаичных особенностей, сближающих его в наибольшей мере со староболгарским языком, языком преславских письменных памятников - с одной стороны, и наличием огромного количества заимствований из тюркских языков, что сближает его с другими балканскими языками и диалектами.

${ }^{1}$ Иванчев Св. Българският език - класически и екзотичен. София, 1988. С. 30.

2 Асенова П. Балканско езикознание. Основни проблеми на Балканския езиков съюз. София: Фабер, 1989. С. 13.

${ }_{3}^{3}$ Иванчев Св. Българският език - класически и екзотичен. София, 1988. С. 21.

${ }^{4}$ Георгиев Вл. К вопросу о балканском языковом союзе // Новое в лингвистике. Языковые контакты. М.: Прогресс, 1972. Вып. 6. С. 401.

${ }^{5}$ Там же.

${ }^{6}$ Там же. С. 409.

${ }^{7}$ Лашкова Л. Основни балкански трансформации на славянските граматични модели и средства в българския език // Общност и многообразие на славянските езици. София, 1997. С. 132.

${ }^{8}$ Демина Е. И. Размышления над явлением языковой интерференции на грамматическом уровне // Традиция и съвременност в българския език. София, 2001. С. 290.

${ }_{9}$ Колесник B. A. Тенденции употребления артикля в болгарских говорах Юга Украины // Слов'янський збірник. Одеса, 2002. Вип. IX. С. 192.

${ }_{10}$ Державин Н. С. Болгарскія колоніи в Россіи (Таврическая, Херсонская и Бессарабская губерніи). София: Мартилен, 1914. С. 49. 
${ }^{11}$ Журавлев В. К. Говор села Криничное (Чешма-Варуита) // Статьи и материалы по болгарской диалектологии СССР. М.: АН СССР, 1955. Вып. 7. С. 18.

${ }^{12}$ Български етимологичен речник (далее - БЕР). Т. 2. София, 1979. С. 143.

${ }^{13}$ Речник на чуждите думи в български и илюстрации и приложения (далее - РЧД). Велико Тьрново: ЕЛПИС, 1995. С. 711.

${ }^{14}$ РЧД. С. 21.

${ }^{15}$ БЕР. Т. 1. София, 1971. С. 4.

16 Там же. С. 9.

${ }^{17}$ Там же. С. 64.

${ }^{18}$ Там же. С. 307.

19 Там же. С. 241.

${ }^{20}$ Там же. С. 243.

${ }^{21}$ Там же. С. 238.

${ }^{22}$ Там же. C. 314.

${ }^{23}$ Там же. С. 317.

${ }^{24}$ Там же. С. 607.

${ }^{25}$ БЕР. Т. 2. София, 1979. С. 546.

${ }^{26}$ РЧД. С. 676

${ }^{27}$ БЕР. Т. 2. София, 1979. С. $365,367$.

${ }^{28}$ Там же. С. 378

${ }^{29}$ БЕР. Т. 6. София, 2002. С. 665.

${ }^{30}$ РЧД. С. 654

${ }^{31}$ БЕР. Т. 2. София, 1979. С. 221.

${ }^{32}$ БЕР. Т. 3. София, 1986. С. 296.

${ }^{33}$ БЕР. Т. 1. София, 1971. С. 510.

${ }^{34}$ БЕР. Т. 3. София, 1986. С. 641.

${ }^{35}$ БЕР. Т. 6. София, 2002. С. 673.

${ }^{36}$ БЕР. Т. 2. София, 1979. С. 127.

${ }^{37}$ Там же. С. 134.

${ }^{38}$ БЕР. Т. 3. София, 1986. С. 693.

${ }^{39}$ БЕР. Т. 4. София, 1995. С. $326,334$.

${ }^{40}$ Там же. С. 339. 